\title{
Implementasi Kurikulum 2013 dalam Peningkatan Kompetensi Psikomotorik dan Afektif Siswa
}

\author{
Nur Ghaniyu Amran', Andi Agustang 2 \\ ${ }^{1,2}$ Pendidikan Sosiologi, Universitas Negeri Makassar, Indonesia \\ Email: ${ }^{1}$ nurghaniyuamran@gmail.com
}

\begin{abstract}
Abstrak. Penelitian bertujuan untuk mendeskripsikan Implementasi Kurikulum 2013 dalam Peningkatan Kompetensi Psikomotorik siswa, dan Implementasi Kurikulum 2013 dalam Peningkatan Kompetensi Afektif siswa. Jenis penelitian deskriptif kualitatif. Penentuan informan menggunakan teknik purpose sampling, dengan kriteria guru yang aktif dan guru mengajar minimal 9 tahun ke atas di SMA Negeri 8 Maros. Jumlah informan sebanyak 5 orang guru yang masih aktif dan mengajar minimal 9 tahun ke atas dan guru yang mengajar pada mata pelajaran IPS di SMA Negeri 8 Mandai. Teknik pengumpulan data yaitu wawancara dan dokumentasi. Teknik pengabsahan data menggunakan member chek. Hasil penelitian menunjukkan bahwa: 1) Implementasi kurikulum 2013 dalam peningkatan kompetensi psikomotorik siswa di SMA Negeri 8 Maros terdiri dari tiga aspek dari guru yaitu (a) keterampilan berdiskusi, (b) keterampilan bertanya dan menjawab pertanyaan, (c) keterampilan mengerjakan tugas. 2) Implementasi kurikulum 2013 dalam peningkatan kompetensi afektif siswa di SMA Negeri 8 Maros yaitu dikelompokkan menjadi enam penilaian yaitu: (a) pemahaman materi pembelajaran dari guru, (b) motivasi belajar siswa, (c) penentuan dan penilaian sikap dar guru, (d) ikut serta dalam kegiatan organisasi, (e) sikap disiplin dan jujur di dalam kelas.
\end{abstract}

Kata Kunci : Kurikulum, penilaian psikomotorik, afektif

\begin{abstract}
This study aims to describe the Implementation of the 2013 Curriculum in Improving Students' Psychomotor Competencies, and the Implementation of the 2013 Curriculum in Improving the Affective Competencies of State Senior High School 8 Maros students. This type of research is descriptive qualitative. Determination of informants using purpose sampling techniques, with the criteria of active teachers and teachers teaching at least 9 years and over at SMA Negeri 8 Maros. The number of informants was 5 teachers who were still active and taught at least 9 years and above and teachers who taught on social studies subjects at SMA 8 Mandai. Data collection techniques are interviews and documentation. The data validation technique uses member check. The results showed that: 1) The implementation of the 2013 curriculum in enhancing the psychomotor competence of students in SMA Negeri 8 Maros consisted of three aspects of the teacher namely (a) discussion skills, (b) questioning and answering questions, (c) skills to do assignments. 2) The implementation of the 2013 curriculum in improving the affective competence of students in SMA Negeri 8 Maros is grouped into six assessments, namely: (a) understanding of learning material from teachers, (b) student learning motivation, (c) determination and assessment of attitudes from teachers, (d ) participate in organizational activities, (e) discipline and honest attitude in the classroom.
\end{abstract}

Keywords : The curriculum, in the assessment of psychomotor,affective competence. 


\section{PENDAHULUAN}

Pendidikan merupakan unsur utama dalam pengembangan Indonesia seutuhnya. Oleh karenanya, pengelolaan pendidikan harus berorientasi kepada bagaimana menciptakan perubahan yang lebih baik. Kurikulum pendidikan di Indonesia sering mengalami pergantian. Dari mulai orde lama, orde baru, sampai reformasi. Sejak indonesia dinyatakan merdeka sejalan dengan itu kurikulum pendidikan mengalami perubahan, yakni pada tahun 1952, tahun 1964, tahun 1968, tahun 1974, tahun 1975, tahun 1984, tahun 1994, dan tahun 2004 (Kurikulum Berbasis Kompetensi), Kurikulum tahun2006 (Kurikulum Tingkat Satuan Pendidikan) serta yang terbaru adalah Kurikulum 2013.

Kurikulum adalah rancangan yang memuat seperangkat mata pelajaran dan materi yang akan dipelajari, atau yang akan diajarkan guru kepada siswa (Yunus, 2013). Dengan kata lain, kurikulum mengacu pada cetak biru pembelajaran untuk memetik suatu hasil yang diiginkan. Tetapi, bagi kebanyakan siswa kurikulum identik dengan tugas pelajaran, latihan atau isi buku pelajaran. Para orang tua cenderung memaknai kurikulum sebagai latihan atau pekerjaan rumah anaknya. Bagi guru, kurikulum seringkali dianggap petunjuk atau pedoman tentang konten kurikulum (materi pelajaran) yang akan diajarkan kepada siswa, di samping strategi, metode atau teknik mengajar serta buku sumber materi ajar. (Ansyar, 2015)

Dalam implementasi kurikulum 2013 guru tetap memengang peranan penting, baik dalam perencanaan, pelaksanaan, maupun evaluasi. Guru juga merupakan barisan pengembangan kurikulum terdepan yang selalu melakukan evaluasi dan penyempurnaan terhadap kurikulum dan pembelajaran.

Setiap implementasi kurikulum, menuntut guru untuk menguasai isi bidang studi, pemahaman karakteristik peserta didik, melakukan pembelajaran yang mendidik dan menyenangkan, serta potensi pengembangan profesionalisme dan kepribadian. (Hidayat, 2015) "mengartikan kurikulum sebagai rangkaian pengalaman yang memiliki kemanfaatan maksimum bagi anak didik dalam mengembangkan kemampuannya agar dapat menyesuaiakan dan menghadapi berbagai situasi kehidupan".

Implementasi kurikulum 2013 yang berbasis karakter dan kompetensi, memerankan guru sebagai pembentuk karakter dan kompetensi peserta didik, yang harus kreatif dalam memilah dan memilih, serta mengembangkan metode dan materi pembelajaran (Fachrudin, 2018). Guru harus profesional dalam pembentukan karakter dan kompetensi peserta didik sesuai dengan karakteristik individual masing-masing, dan harus tampil menyenangkan di hadapan peserta didik dalam kondisi dan suasana bagaimanapun (Daryanto, 2016).

Guru harus sadar bahwa dalam melaksanakan tugasnya selalu di tuntut untuk bersungguh-sungguh dan harus menyadari bahwa yang dianggap baik dan benar saat ini belum tentu benar dimasa yang akan datang (Karwono, 2017). Oleh karena itu guru dituntut untuk selalu meningkatkan pengetahuan keterampilan dan kemampuan dalam rangka melaksanakan tugas profesinya.

Rumusan kurikulum tingkat satuan pendidikan dalam sistem pendidikan nasional disebutkan bahwa dalam penilaian pembelajaran meliputi tiga aspek yakni aspek kogntif, afektif, dan psikomotorik (Kurniasih, 2014). Aspek psikomotorik tersebut termasuk kemampuan guru melibatkan keterampilan atau kemampuan memberikan pembelajaran kepada peserta didik.

Keterampilan guru dalam pembelajaran dapat dilihat dari kemampuan guru dalam memberikan pemahaman kepada siswa tentang materi pelajaran yang disampaikan. Pembelajaran keterampilan akan efektif bila menggunakan prinsip belajar sambil mengerjakan (Sunarti, 2014). Keterampilan yang dilatih melalui praktik secara berulangulang akan menjadi kebiasaan dan otomatis dilakukan. Keberhasilan pengembangan aspek kognitif juga akan berdampak positif terhadap pengembangan aspek psikomotorik.

Seorang guru yang dapat memberikan kecakapan psikomotorik kepada siswa, akan berdampak pada kemampuan siswa yang memiliki keterampilan jasmaniah baik kuantitasnya maupun kualitasnya (Suheman, 2014). Namun, di samping kecakapan psikomotorik tidak terlepas dari kecakapan kognitif juga banyak terikat oleh kecakapan afektif. Jadi, kecakapan psikomotorik siswa merupakan manifestasi wawasan pengetahuan dan kesadaran serta sikap mentalnya.

Kurikulum didasarkan pada model kurikulum berbasis kompetensi. Model 
kurikulum berbasis kompetensi ditandai oleh pengembangan kompetensi berupa sikap, pengetahuan, keterampilan berpikir, dan keterampilan psikomotirik yang dikemas dalam berbagai mata pelajaran (Haryati, 2009).

Pembelajaran afektif dari suatu proses dan hasil belajar menekankan pada bagaimana siswa bersikap dan bertingkah laku di dalam lingkungan masyakatnya (Supardi, 2015). Dalam pembelajaran ini terdapat beberapa ranah afektif yang berkaitan dengan sikap yang terdiri dari : penerimaan, jawaban atau reaksi, penilaian organisasi, dan internalisasi.

SMA Negeri 8 Maros merupakan salah satu sekolah yang menerapkan Kurikulum 2013. Dengan di terapkannya kurikulum 2013 guru berharap siswa dapat lebih kreatif karena di dalam kurikulum terdapat salah satu komponen pembelajaran. Di SMA Negeri 8 Maros merupakan sekolah SMA yang ada di Kabupaten Maros yang merupakan salah satu yang banyak diminati oleh masyarakat, dan memiliki kualitas baik dan fasilitasi yang baik. Tidak hanya dalam bidang agama saja, tetapi menjadi yang terbaik dalam segala bidang pendidikan. Berdasarkan observasi awal yang dilakukan oleh peneliti terungkap bahwa di SMA Negeri 8 Maros sejak awal menerapkan kurikulum 2013. Selain itu tanggapan beragam yang dilontarkan pihak-pihak yang terlibat dalam kurikulum 2013, terutama siswa di SMA Negeri 8 Maros. Umumnya penerapan kurikulum 2013 berasal dari bagaimana proses siswa dalam hal peningkatan keterampilan dan sikap siswa dalam kelas. Berangkat dari hal tersebut, maka peneliti ingin mengetahui bagaimana implementasi kurikulum 2013 dalam peningkatan kompetensi psikomotorik dan afektif siswa.

Dari uraian di atas maka penulis memilih permasalahan ini karena dianggap menarik untuk diteliti. Hal inilah yang memperkuat dipilihnya judul "Implementasi Kurikulum 2013 dalam Peningkatan Kompetensi Psikomotorik dan Afektif Siswa (Studi SMA Negeri 8 Maros)"

\section{METODE}

Jenis penelitian ini adalah
kualitatif deskriptif
dengan pendekatan deskriptif. Penelitian kualitatif menggunakan metode kualitatif (Sugiyono, 2015). Metode kualitatif ini digunakan karena beberapa pertimbangan, yaitu: petarama, menyesuaikan metode kualitatif lebih mudah apabila berhadapan dengan kenyataan-kenyataan ganda, kedua, metode ini menyajikan secara langsung hakikat hubungan antara peneliti dan responden, dan ketiga, metode ini lebih peka dan lebih dapat menyesuaikan diri dengan banyak penajaman pengaruh bersama dan terhadap bersama dan terhadap pola-pola nilai yang dihadapi. (Agustang, 2013)

Teknik dalam menentukan informan menggunakan purpose sampling, dengan kriteria yaitu guru yang mengajar mininal 9 tahun di SMA Negeri 8 Mandai, guru yang mengajar pada mata pelajaran IPS di SMA Negeri 8 Mandai. Jumlah informan sebanyak 5 orang guru yang mengajar pada mata pelajaran IPS dan yang telah mengajar minimal 9 tahun. Teknik pengumpulan data yang digunakan yaitu observasi, wawancara, dan dokumentasi. Data yang diperoleh dianalisis dengan desktiptif kualitatif yaitu mereduksi data, menyajikan data dan penarikan kesimpulan. Teknik pengabsahan data menggunakan member check.

\section{HASIL DAN PEMBAHASAN}

1) Implementasi Kurikulum 2013 dalam peningkatan penilaian kompetensi psikomotorik di SMA Negeri 8 Mandai. Adapun Implementasi Kurikulum 2013 dalam penilaian kompetensi psikomotorik di SMA Negeri 8 Mandai

a.Diskusi : Metode diskusi adalah metode yang dilakukan oleh salah satu guru untuk mengaktifkan siswa dalam proses pembelajaran dikelas. Kemudian pada saat dikusi berlangsung guru juga menilai bagaimana siswa aktif dalam menyampaikan pendapat, bahasa yang digunakan sudah sesuai dengan bahasa yang seharusnya digunakan yaitu bahasa yang baku dan bagaimana cara bicara anak tersebut pada saat proses diskusi berlangsung, apakah anak tersebut sudah berbicara yang sopan meskipun dengan teman sebayanya apalagi dengan gurunya. Dengan metode seperti ini guru bisa menilai anak-anak bisa lebih aktif dalam proses pembelajaran, seperti pada saat diskusi anak tidak hanya membacakan makalah tersebut tetapi menjelaskannya juga dan mampu menjawab pertanyaan yang diberikan oleh temannya yang lain. (Haling, 2007) diskusi yang dimaksudkan disini adalah pertanyaan mempunyai kecenderungan untuk merangsang pembelajar menggunakan pengalaman dan 
fakta-fakta yang telah dipelajari untuk menganalisa masalah-masalah yang kompleks sifatnya, atau pertanyaan yang lebih berbelit. Pemecahan atas masalah, atau jawaban atas pertanyaan tersebut bisanyanya tidak hanya tunggal, melainkan banyak kemungkinannya. Demikian pula tidak bersifat faktual, melainkan lebih berupa pendapat/pandangan atau sikap.

b. Tanya Jawab : Selaian metode diskusi yang diterapkan oleh guru untuk mengaktifkan siswa, guru juga menggunakan metode tanya jawab dimana biasa guru dengan cara mengaktifkan siswa guru memberikan penguatan seperti pancingan, gambaran mengenai materi yang dijelaskan atau motivasi bertanya. Dalam menjabaw pertanyaan biasa ada siswa yang lansung menangkap pertanyaan yang diberikan oleh Bapak/ Ibu guru terkadang ada juga yang lambat dalam mencerna pertanyaan yang diberikan. Selain itu Bapak/ Ibu guru juga menggunakan beberapa model pembelajaran untuk mengaktifkan siswa dalam hal bertanya dan menjawab pertanyaan

c. Penugasan : Guru juga menilai keterampilan siswa dengan menilai kreativitas siswa dalam mengerjakan tugas yang diberikan, misalnya tugas yang diberikan itu baik tugas individu maupun kelompok seperti memberikan tugas makalah disertai power pointnya disini guru menilai bentuk makalah dan power pointnya apakah siswa sudah bisa kreatif dalam membuat power point. Selain itu guru juga menilai ketepatan siswa mengumpulkan tugas.

Dalam penelitian ini peneliti menggunakan teori struktural fungsional yang diadopsi oleh (Ritzer, 2012) yang berpendapat bahwa terdapat empat imperatif fungsional untuk semua "tindakan" yaitu skema AGIL.

2) Implementasi Kurikulum 2013 dalam peningkatan penilaian kompetensi afektif siswa di SMA Negeri 8 Maros

Adapun implementasi kurikulum 2013 dalam penilaian kompetensi afektif siswa di SMA Negeri 8 Mandai

a. Menerima atau Merespon

Guru juga menilai siswa dari sikapnya seperti menilai siswa dari bagaimana siswa menerima dan merespon materi yang diberikan oleh Bapak/Ibu guru akan tetapi tergantung juga dengan bagaimana guru bisa mengelola kelas dan manajemen kelasnya dan tergantung juga dari jika mereka bersungguh-sungguh maka
Suatu fungsi adalah "suatu kompleks kegiatankegiatan yang diarahkan kepada pemenuhan suatu kebutuhan atau kebutuhan-kebutuhan sistem itu". AGIL merupakan singkatan dari adaption (Adaptasi), goal attainment (Pencapaian Tujuan), Integration (Integrasi), latency (Pemeliharaan Pola). Agar suatu sistem dapat bertahan, maka suatu sistem harus melaksanakan keempat fungsinya dimana jika ada satu sistem yang rusak maka sistem yang lainnya berpengaruh atau rusak.

Mengenai peningkatan kurikulum 2013 dalam penilaian kompetensi psikomotorik menunjukkan bahwa teori parsons yang di sebut AGIL yang artinya bahwa setiap sistem saling berkaitan satu sama lainnya dan jika ada satu sistem yang tidak berfungsi maka akan mempengaruhi sistem yang lain Kemudian hasil penelitian ini juga terkait dengan hasil penelitian Agussalim dengan judul penelitian "Persepsi Siswa Terhadap Implementasi Kurikulum 2013 di SMA Negeri 9 Makassar"

Hasil penelitian ini menunjukkan bahwa 2013 siswa di tuntut untuk mencari informasi, melihat, mendengar, membaca, dan menyimak materi pembelajran. Selain itu roses pembelajarn dapat dilakukan melalui kegiatan diskusi, kerja kelompok, dan diskusi kelas. Sedangkan hasil penelitian mengenai Implementasi kurikulum 2013 dalam peningkatan kompetensi psikomotorik siswa yang hasil penelitiaanya menjelaskan bahwa guru menilai siswa dari berbagai macam jenis penilaian yang ada pada kurikulum 2013 dimana siswa harus lebih aktif di kelas dan guru juga membantu siswa untuk lebih aktif lagi dalam proses pembelajaran di kelas.

mereka akan merenspon dan menerima dengan baik, tetapi menurut guru disana siswa sudah mampu merespon dan menerima materi yang diajarkan ada yang belum cuman sisa satu atau dua orang saja, dengan itu guru biasa memberikan motivasi atau nasehat kepada siswa yang kurang mampu dalam menerima pelajaran atau memberikan pendekatan kepada siswa karena terkadang siswa ada masalah dalam keluarga jadi guru harus mampu melakukan pendekatan.

b. Minat/ Perhatian Siswa

Selain menilai anak dengan bagaimana anak menerima dan merespon materi yang diajarkan 
guru juga menilai bagaimana minat/ perhatian siswa dalam proses pembelajaran. sering kali memberikan anak motivasi berupa pemberian reward atau hadiah kepada anak yang mampu menjawab pertanyaan misalkan jadi anak tersebut terus termotivasi dan minat belajar anak juga semakin meningkat dan anak tersebut lebih semangat lagi dalam proses pembelajaran, dengan pemberian reward atau penghargaan kepada peserta didik dapat juga meningkatkan minat/perhatian siswa karena dengan sendirinya akan merasa dihargai dan bangga dengan pencapaiannya sehingga mereka akan termotivasi lagi untuk belajar lebih giat sehingga prestasi belajarnya akan meningkat.

c. Penilaian dan Penentuan Sikap

Yang dimaksud disini bagaimana sikap dan perilaku anak lebih kepada bagaimana moral anak juga bagaimana ketertiban anak dalam kelas seperti berdasar beberapa hasil wawancara saya dengan beberapa informan guru bahwa sikap anak seperti sopan santunnya tingkah lakunya rata-rata anak di SMA Negeri 8 Maros sudah bagus karena di sekolah ini terapkan yang paling pertama itu sikap sopan santun dan tingkah laku siswa harus bagus ada juga beberapa siswa yang kurang sopan tapi jika ada yang tidak sopan tindakan yang diberikan guru berupa sanksi atau memberikan nasehat atau teguran.

d. Penilaian Organisasi

Maksudnya disini bagaimana anak dalam berorganisasi misalnya anak yang ikut berorganisasi dengan anak yang tidak ikut organisasi apakah mempunyai sikap sopan santun atau tingkah laku yang berbeda. Menurut beberapa informan guru yang saya wawancarai adalah guru di SMA Negeri 8 Mandai memperhatikan bahwa siswa yang ikut organisasi memang sikap, tingkah lakunya bagus karena disana juga di ajarkan bagaimana berprilaku yang baik apalagi kalau berbicara dengan orang lebih tua tapi pada dasarnya samaji sebenarnya cuman memang sedikit lebih baik anak yang ikut organisasi dan itu juga menjadi contoh untuk temannya.

e. Pembentukan Pola Hidup

Dalam pembentukan pola hidup ini yang nilai guru seperti kedisiplinan siswa, bagaimana ketekunan belajar siswa. Menurut beberapa informan guru yang saya wawancarai mengatakan bahwa rata-rata dan sebagian besar siswa sudah disiplin karena ada tata aturan yang diterapkan jika ada siswa yang melanggar maka ada sanksi yang didapatkan tetapi pada saat di dalam kelas seperti contohnya ada anak yang pada saat proses pembelajaran bajunya keluar atau jika laki-laki rambutnya panjang, guru biasa memberikan teguran jika sudah ditegur tapi tidak dilaksanakan biasanya guru langsung bawa ke BK biar mereka yang ambil alih karena siswa mempunyai beberapa karakter yang berbedabeda jadi di sini guru juga tidak boleh langsung memarahi atau memberikan hukuman lebih tepatnya guru memberikan nasehat atau melakukan pendekatan kepada siswa karena ada juga siswa yang tidak bisa jika dikerasi.

Jika dilihat berdasarkan bagaimana ketekunan belajar siswa sudah bagus sepenuhnya tergantung bagaimana gurunya di dalam memberikan materi pelajaran bagaimana manajemen kelasnya bagaimana pengelolaan kelasnya karena ada juga itu siswa yang kalau belajarki na liatki dari gurunya siapa guru yang mengajar, ada juga yang na lihat dari mata pelajarannya kalau mata pelajaran yang dia sukai dia juga semangat. Tapi untuk membangkitkan semangat belajar siswa kita harus memberikan penguatan berupa pancingan atau motivasi belajar.

Berdasarkan yang telah dipaparkan diatas, dapat diketahui kata kuncinya bahwa perlu kita ketahui penilaian yang diberikan oleh guru berdasarkan kurikulum 2013 sangatlah efektif karena selain mengantifkan siswa dalam proses mejar mengajar di kelas siswa juga di dorong untuk lebih mandiri baik itu mencari pokok-pokok materi yang akan diajarkan. Seperti yang dilakukan oleh guru di SMA Negeri 8 Mandai banyak penilaian yang mereka lakukan misalnya dalam hal keterampilan siswa bagaimana siswa mampu berdiskusi, menjawab pertanyaan dan mengumpulkan tugas dengan tepat waktu ini juga tidak lain dari bagaimana guru mengelola kelas dan manajemen kelasnya. Kemudian penilaian afektif yang dilakukan guru yaitu guru menilai siswa dari bagaimana siswa menerima dan merespon pada saat guru menjelaskan materi yang sedang berlangsung, bagaimana minat belajar siswa, sikap sopan santun siswa semua dinilai guru berdasarkan pelaksanaan kurikulum yang berlaku.

Penilaian ini sudah di pertimbangkan untuk di terapkan di sekolah ini. Terkait dengan hasil penelitian Sutrisno dan Muhammad Syukur dengan judul penelitian "Peranan Pengawas Sekolah Terhadap Pelaksanaan Kurikulum 2013 di SMA Negeri 17 Makassar" 
Hasil penelitian ini menunjukkan bahwa penelitian ini dilatarbelakangi mengenai seorang guru dapat melaksanakan kewajiban sebagai pelaksana kurikulum dengan baik jika ada yang mengawasi dan mengontrol setiap pelaksaan PBM di dalam ruang kelas karena adanya pengawasan dan pengontrolan pada setiap proses PBM yang dilakukan antara guru dan peserta didik makan guru akan menjalankan sistem kurikulum pendidikan nasional tersebut dengan baik dan benar sesuai dengan yang terdapat pada kurikulum tersebut.

\section{SIMPULAN DAN SARAN}

Implementasi Kurikulum 2013 dalam peningkatan penilaian Psikomotorik siswa di SMA Negeri 8 Mandai adalah : Pertama, bagaimana cara siswa berdiskusi dikelas, kedua bagaiamana siswa menjawab pertanyaan yang diberikan oleh Bpak/Ibu guru, ketiga bagaiamana ketetapatan dan kereativitas siswa dalam mengumpulkan dan mengerjakan tugas. Implementasi Kurikulum 2013 dalam peningkatan kompetensi Afektif siswadi SMN Negeri 8 Mandai : pertama, menerima/ merespon materi yang diberikan oleh Bapak/Ibu guru, kedua bagaiaman minat/ perhatian siswa dalam proses pembelajaran, ketiga penilaian dan penentuan sikap siswa, keempat penilaian organisasi apakah siswa yang ikut oraganisasi mempengaruhi sikapnya, kelima pembentukan pola hidup. diharapkan dapat dijadikan sebagai bahan masukan para guru mengenai penilaian terhadap peserta didik terutama pada saat proses belajar mengajar berlangsung agar peserta didik lebih memahami apa yang disampaikan oleh guru sehingga guru dapat memberikan penilaian juga dengan baik.

\section{DAFTAR RUJUKAN}

Agustang, A. (2013). Telaah Kritis tentang Model pendekatan Penelitian Kualitatif dan Kuantitaif.

Ansyar. (2015). Kurikulum ( hakikat, fondasi, desain dan pengembangan ). Kencana
Prenademia Group.

Daryanto, A. dan. (2016). Evaluasi dan Penilaian Pembeajaran Kurikulum. PT. Gava Media.

Fachrudin. (2018). Implementasi Kurikulum 2013. 3, 267.

Haling, A. (2007). Perencanaan Pembelajaran. Badan Penerbit Universitas Negeri Makassar.

Haryati, M. (2009). model dan teknik Penilaian pada tingkat Satuan Pendidikan. Gaung Persada Press.

Hidayat, R. (2015). Pengantar Sosiologi Kurikulum. PT.Raja Grafindo Persada.

Karwono. (2017). Belajar dan Pembelajaran. PT. Raja Grafindo Persada.

Kurniasih, I. (2014). Sukses Mengimplementasikan Kurikulum. Kata Pena.

Ritzer, G. (2012). Teori Sosiologi. Pustaka belajar.

Sugiyono. (2015). metode penelitian Pendidikan (Pendekatan Kuantitatif dan Kualitatif). Alfabeta.

Suheman. (2014). Implementasi Kurikulum 2013 Pendidikan Jasmani. volume 1.

Sunarti, R. (2014). Penilaian dalam Kurikulum 2013. CV. Andi Offset.

Supardi. (2015). Penilaian Autentik Pembelajaran Afektif, kognitif dan Psikomotor (2015th ed.). PT Raja Grafindo Persada.

Yunus, A. (2013). Desain Sistem Pembelajaran dalam Kompleks Kurikulum. Pt.Refika Aditama. 